\title{
Gonadotropin-dependent pubertal disorders are common in patients with virilizing adrenocortical tumors in childhood
}

\author{
Monica F Stecchini ${ }^{1}$, Zilda Braid ${ }^{1}$, Candy B More ${ }^{1}$, Davi C Aragon ${ }^{1}$, Margaret Castro ${ }^{2}$, Ayrton C Moreira ${ }^{2}$ and \\ Sonir R Antonini ${ }^{1}$ \\ ${ }^{1}$ Department of Pediatrics, Ribeirao Preto Medical School, University of Sao Paulo, Ribeirao Preto, Sao Paulo, Brazil \\ ${ }^{2}$ Department of Internal Medicine, Ribeirao Preto Medical School, University of Sao Paulo, Ribeirao Preto, Sao Paulo, Brazil \\ Correspondence should be addressed to S R Antonini: antonini@fmrp.usp.br
}

\begin{abstract}
Objective: To investigate the impact of early exposure to androgen excess on gonadotropin-dependent puberty (GDP) and final height (FH) of patients with androgensecreting adrenocortical tumors (ACT) in childhood.

Methods: Retrospective cohort study. Occurrence of GDP and achievement of FH were evaluated. Central precocious puberty (CPP) and early fast puberty (EFP) were considered pubertal disorders. Patients with normal puberty and pubertal disorders were compared.

Results: The study included 63 patients (44F), followed in a single institution from 1975 until 2017. At diagnosis of ACT, median age was 25.8 months; duration of signs, 6 months; stature SDS, 0.5 ( -3.6 to 3.9) and bone age advancement, 14.7 months ( -27.9 to 85.4). To date, 37 patients developed GDP: 26 had normal puberty; one, precocious thelarche; seven, CPP and three, EFP. GnRHa effectively treated CPP/EFP. Tall stature and older age at diagnosis of ACT were associated with risk of CPP alone (RR 4.17 (95\% Cl 1.17-14.80)) and CPP/EFP (RR 3.0 (95\% Cl 1.04-8.65)). Recurrence/metastasis during follow-up were associated with risk of CPP alone (RR 4.17 (95\% Cl 1.17-14.80)) and CPP/EFP (RR 3.0 (95\% Cl 1.12-8.02)). Among the 19 patients that reached $\mathrm{FH}$, stature SDS dropped from 1.4 to -0.02 since diagnosis of ACT $(P=0.01)$. Seventeen achieved normal $\mathrm{FH}$. There was no difference in FH SDS between patients with normal puberty and pubertal disorders $(P=0.75)$.

Conclusions: Gonadotropin-dependent pubertal disorders are common in patients with androgen-secreting ACT in childhood. FH is usually not impaired. The study reinforces the importance of close follow-up after surgery to identify and treat consequences of early exposure to androgen excess.
\end{abstract}

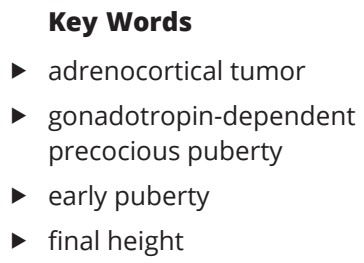

Endocrine Connections (2019) 8, 579-589

\section{Introduction}

Gonadotropin-dependent precocious puberty or central precocious puberty (CPP) is caused by reactivation of the hypothalamic-pituitary-gonadal axis (HPG), while gonadotropin-independent precocious puberty or peripheral precocious puberty (PPP) is caused by autonomous secretion of sex steroids from ovaries, testicles or adrenals, before the age of 8 years in girls and 9 years in boys (1). In some circumstances, PPP can trigger https://ec.bioscientifica.com

https://doi.org/10.1530/EC-19-0141

(c) 2019 The authors Published by Bioscientifica Ltd

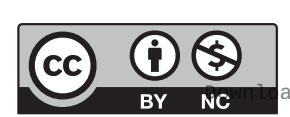

This work is licensed under a Creative Commons Attribution-NonCommercial 4.0 International License. ded from Bioscientifica.com at 04/26/2023 12:15:32AM 
CPP through mechanisms that are not well understood, but that may be related to the skeletal maturation induced by androgen excess (2).

The development of secondary CPP has been extensively reported in patients with lately diagnosed or poorly controlled congenital adrenal hyperplasia (CAH), and other conditions associated with androgen excess, usually after initiation of treatment of the underlying disease $(3,4,5,6,7,8,9,10,11,12,13,14,15,16)$. In this context, androgen-secreting adrenocortical tumors (ACTs), which usually present with virilizing features, linear growth acceleration and bone age (BA) advancement (17), could also lead to secondary CPP. However, this outcome has been considered uncommon in ACTs (18).

ACTs are rare in children worldwide, with an overall incidence of $0.2-0.4$ cases per million per year (17). However, their incidence is 10-15 times higher in Southern and Southeastern Brazil (19), where 75-97\% of the patients harbor a specific TP53 mutation. The P53 p.R337H is the most significant and well-characterized genetic risk for ACT in these regions; it is widespread due to a founder effect $(20,21,22,23,24)$. This mutation was initially described in association with ACTs in Brazilian children (21), but it has been shown to be associated with the development of other types of cancer in adulthood, in the context of Li-Fraumeni syndrome $(25,26)$.

Pediatric ACTs are more commonly diagnosed in early childhood ( $<4$ years) and predominantly affect females $(19,23)$. The majority of these tumors secrete hormones, especially androgens and cortisol, and the most common clinical presentation is a virilizing syndrome - isolated or associated with Cushing syndrome (17). The diagnosis of ACT is suggested by clinical, laboratory and imaging features and confirmed by pathological findings after tumor resection (17). In the pediatric population, imaging criteria and histologic classification systems used to distinguish benign from malignant tumors for adult patients do not reflect the future tumor behavior and the patient's outcome. Therefore, the term 'ACT' is preferred and represents the sum of adenomas and carcinomas $(17,27,28)$. Open adrenalectomy is the treatment of choice, which may be complemented with mitotane and chemotherapy, based on tumor staging (29).

Although morbidity (metastasis, recurrence and complications of ACT treatment) and mortality in patients with ACTs are well documented $(17,19,23,24)$, the late effects of early exposure to androgen excess on gonadotropin-dependent puberty and on growth have been scarcely presented in case reports $(30,31,32,33)$, in small series of patients $(18,34)$ or in studies with other purposes $(19,24)$.

We hypothesized that children with androgensecreting ACTs may be at increased risk of developing early activation of the HPG axis, and that final height (FH) may not be impaired if adequate treatment is used. Therefore, the objective of this study was to investigate the impact of early exposure to androgen excess on gonadotropindependent pubertal development and on FH of patients treated for androgen-secreting ACTs during childhood, in a single reference center, over the period of four decades.

\section{Subjects and methods}

\section{Study design and patients}

This was a retrospective cohort study performed at the Hospital of Ribeirao Preto Medical School from the University of Sao Paulo (Brazil). The study was approved by this institution's ethics committee and conducted in compliance with the Declaration of Helsinki.

Records from patients followed at this institution, from September 1975 until September 2017, were reviewed. Inclusion criteria included surgical treatment of an androgen-secreting ACT before the age of 18 years. Exclusion criteria included presence of other conditions that also influence growth and pubertal development.

Epidemiological, clinical, anthropometrical, hormonal, radiological, histopathological and genetic data were collected from the eligible patients' medical records.

\section{Descriptive data}

The age at diagnosis of ACT and the age of tumor resection were considered the same - and presented as 'age at diagnosis of $\mathrm{ACT}^{\prime}$ - because surgery was performed shortly after the clinical/biochemical/radiological diagnosis of ACT in all cases.

The duration of ACT signs reflected the period between the family's perception of clinical signs and the diagnosis of ACT. The main clinical presentation was divided as: asymptomatic; unspecific signs - weight loss, fever, abdominal mass or pain; virilizing syndrome - precocious pubarche, clitoris or penile enlargement, axillary hair and odor, acne, muscular hypertrophy, aggressiveness - denoting androgen excess; and Cushing syndrome - weight gain, central obesity, facial plethora, violet striae - denoting cortisol excess (17).
This work is licensed under a Creative Commons Attribution-NonCommercial 4.0 International License. ded from Bioscientifica.com at 04/26/2023 12:15:32AM via free access 
Height and body mass index (BMI) were expressed in standard deviation scores (SDS), according to the World Health Organization (WHO) curves for children of 0-5 years (2006) and 5-19 years (2007), using the statistical software LMSgrowth 2002-12 Medical Research Council, UK. Short stature was defined as stature $<-2$ SDS and tall stature as stature $>+2$ SDS (35). FH was considered when BA was 15 and 17 years for females and males, respectively. Target height and range were calculated for girls as ((mother's stature + father's stature -13$) / 2 \pm 9)$ and for boys as ((father's stature + mother's stature +13$) / 2 \pm 10$ ), in centimeters (36). Obesity was defined as BMI $>+3$ SDS in children from 0 to 5 years or $>+2$ SDS in children from 5 to 19 years, while overweight was defined as BMI $>+2$ SDS in children from 0 to 5 years or $>+1$ SDS in children from 5 to 19 years.

Pubertal stage was described according to Marshall and Tanner classification $(37,38)$. BA was determined by radiologists and confirmed by the attending endocrinologists, based on the Greulich-Pyle method (39). It was presented as delta $(\Delta)$ BA (difference between BA and chronological age) and classified as advanced when $\Delta$ BA was $>+1$ SDS for sex and chronological age (1).

In terms of hormone production, ACTs were categorized as pure androgen-secreting tumors (virilizing tumors or V-ACT), when androgen excess was isolated or androgen- and cortisol-secreting tumors (mixed tumors or M-ACT), when androgen excess was combined with autonomous cortisol secretion, confirmed by a dexamethasone suppression test (17). Plasma concentration of dehydroepiandrosterone sulfate (DHEA-S), androstenedione, testosterone and 17-hydroxyprogesterone (17-OHP), as well as cortisol (17), was determined by immunoassays.

The diagnosis of ACT was suggested by clinical, laboratory and imaging features and confirmed by pathological findings after tumor resection.

Tumor stage was established according to the International Pediatric Adrenocortical Tumor Registry (IPACTR) criteria, as I, II, III or IV (29).

Sanger sequencing of TP53 exon 10 was routinely performed for patients with the diagnosis of ACT to investigate the presence of the P53 p.R337H mutation (17).

\section{Outcomes and predictors}

The development of gonadotropin-dependent pubertal disorders was defined as the primary outcome of this study. CPP was defined as the presence of breast in girls
(Tanner stage 2 - thelarche) before 8 years and of testicular enlargement $\left(\geq 4 \mathrm{~cm}^{3}\right)$ in boys before 9 years, with progression of pubertal signs, secondary to activation of the HPG axis. Early puberty (EP) - although within the normal pubertal range - was defined as the presence of breast between 8 and 9 years in girls and of testicular enlargement between 9 and 10 years in boys. Fast puberty (FP) was defined as progression from one pubertal stage to another in less than 6 months (1). The combination of EP and FP was named early fast puberty (EFP) $(40,41)$. Precocious menarche was defined as cyclic vaginal bleeding before 9 years (1). CPP and EFP were considered pubertal disorders.

Sex, age, duration of ACT signs, Tanner stage for pubic hair, stature SDS, $\Delta$ BA, tumor type, DHEA-S and testosterone levels, and tumor stage at diagnosis of ACT, recurrence and/or metastasis during follow-up, as well as $\mathrm{FH}$, were compared between patients with normal puberty and with pubertal disorders.

\section{Statistical analysis}

Quantitative variables were expressed as median and range, if continuous, or as absolute number and fractions, if discrete.

Gonadotropin-dependent pubertal development was analyzed based on the comparison of two groups: normal puberty (normal onset +EP without FP) and pubertal disorders (CPP + EFP). Relative risk (RR) was used to investigate associations based on categorical variables: sex (female or male), age ( $\geq 4$ or $<4$ years), duration of ACT signs ( $\geq 6$ or $<6$ months), Tanner stage for pubic hair $(>2$ or $\leq 2)$, stature SDS $(>2$ or $\leq 2$ ), BA (advanced or not advanced), tumor type (V-ACT or M-ACT), tumor stage (III/IV or I/II), DHEA-S and testosterone levels (both: $\geq 300$ or $<300 \mathrm{ng} / \mathrm{dL}$ ) at diagnosis of ACT, and recurrence/metastasis during follow-up (present or absent). The definition of these categories was based on the assumption that longer and more severe exposure to androgen excess would increase the risk of pubertal disorders. The results were presented as RR, with 95\% confidence intervals (CI).

Wilcoxon rank-sum test was used to compare continuous variables between groups. Wilcoxon signedrank test was used to compare initial and final stature SDS of patients that reached FH. For the hypothesis tests, significance level of $\alpha=0.05$ was used.

The software STATA 15.1 was used for statistical analysis.

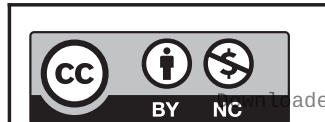

This work is licensed under a Creative Commons Attribution-NonCommercial 4.0 International License. ded from Bioscientifica.com at 04/26/2023 12:15:32AM via free access 


\section{Results}

\section{Subjects}

From September 1975 until September 2017, 70 patients with the diagnosis of ACT before the age of 18 years were followed at the Hospital of Ribeirao Preto Medical School, University of Sao Paulo - which is located in the Southeast region of Brazil. Of these, the records of six female patients were not included due to lack of surgical treatment $(n=1)$, lack of proper hormonal assessment before diagnosis of ACT $(n=3)$ and presence of isolated cortisol excess $(n=2)$. Additionally, the record of one female patient was excluded due to the presence of an overgrowth syndrome - Beckwith-Wiedeman syndrome $(n=1)$. Therefore, the records of 63 patients with the diagnosis of an androgensecreting ACT, both V-ACT and M-ACT, before the age of 18 years were eligible for this study (Fig. 1).

\section{General characteristics}

Table 1 shows the general features of the 63 patients included in the study. The majority were female (44/63) and white (58/63), with median age at diagnosis of ACT of 25.8 months (2.1-192.2). Median duration of ACT signs was six months $(0-60)$ : $<6$ months for 30 patients, between 6 and 12 months for 19 patients, between 12 and 24 months for 9 patients and $\geq 24$ months for 5 patients. Family history of ACT was present in $8 / 63$ and of other types of cancer in $1 / 3$ of the patients.

The majority of patients (54/63) presented clinically with a virilizing syndrome, seven also had Cushing syndrome and two patients were asymptomatic. In these two patients, the diagnosis was made because of significant family history of ACT and presence of the P53 p.R337H mutation - which motivated hormone assessment - in one case, or because of altered 17-OHP in the neonatal screening for $\mathrm{CAH}$ - which is an unusual form of diagnosis - in the other. However, hormonal assessment revealed that the majority of the tumors $(55 / 63)$ were actually M-ACT.

Median SDS for stature and for BMI at diagnosis of ACT was 0.50 ( -3.55 to 3.89 ) and 1.38 (-1.88 to 6.33 ), respectively. Eleven patients had tall stature and two, short stature. Twelve patients had obesity and nine, overweight. There was no difference regarding stature SDS $(P=0.38)$ or BMI SDS $(P=0.18)$ between patients with V-ACT (stature SDS: 1.24 (-0.08 to 1.97$)$; BMI SDS: 0.55 (-0.63 to 2.45$)$ ) and patients with M-ACT (stature SDS: 0.48 ( -3.55 to 3.89); BMI SDS: 1.41 (-1.88 to 6.33)).

Median DHEA-S was $748.0 \mu \mathrm{g} / \mathrm{dL} \quad(32.0-4950.0)$ (19.5 $(0.8-128.7) \mu \mathrm{mol} / \mathrm{L})$ and median testosterone was $242.5 \mathrm{ng} / \mathrm{dL}$ (33.6-1800.0) (8.4 (1.2-62.4) nmol/L).

BA was available for 52 out of the 63 patients: it was advanced in 33, adequate for chronological age in 17 and delayed in 2 patients. In general, BA was 14.7 months advanced (-27.9-85.4). Median $\Delta$ BA was 17.5 months (0.4-49.1) for patients with V-ACT and 11 months (-27.9-85.4) for patients with M-ACT $(P=0.84)$.

Tumor stage I was the most frequent (38/63), followed by III (11/63), II (8/63) and IV (6/63). The mutational status was available for 52 out of the 63 patients: $48 / 52$ harbored the P53 p.R337H mutation.

Median duration of follow-up was 73.7 months (0.2-295.4). During this period, 16 patients had recurrence and/or metastasis, 17 were treated with chemotherapy (mitotane; combination of other chemotherapy agents - mainly cisplatin, doxorubicin, etoposide; or mitotane associated with these agents) and only three patients
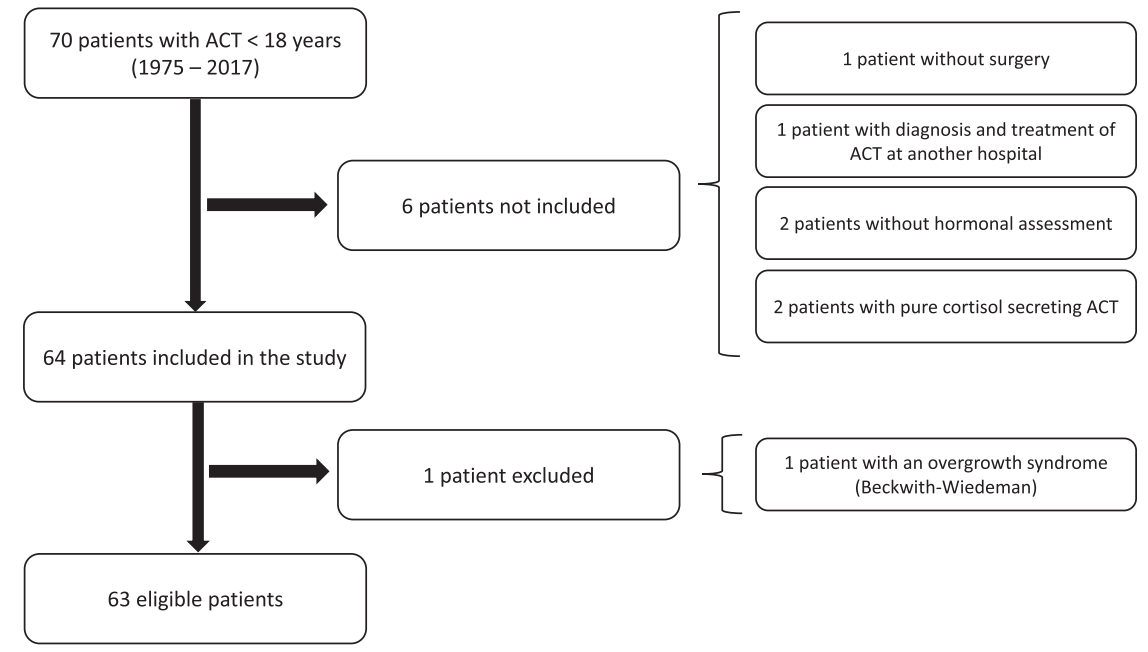

63 eligible patients
Figure 1

Selection of patients with diagnosis of adrenocortical tumor in childhood according inclusion and exclusion criteria. 
Table 1 General features of the 63 patients with adrenocortical tumors <18 years from 1975 to 2017.

\begin{tabular}{|c|}
\hline Features \\
\hline At diagnosis of ACT \\
\hline Sex \\
\hline Female \\
\hline Male \\
\hline Skin color \\
\hline White \\
\hline Nonwhite \\
\hline Age (months) \\
\hline Duration of ACT signs (months) \\
\hline Family history of ACT \\
\hline Family history of other types of cancer \\
\hline Clinical features \\
\hline Pubarche \\
\hline Macrogenitossomy \\
\hline Clitorimegaly \\
\hline Acne \\
\hline Axillary odor \\
\hline Muscular hypertrophy \\
\hline Deep voice \\
\hline Aggressiveness \\
\hline Irritability \\
\hline Hypertension \\
\hline Present \\
\hline Absent \\
\hline Data not available \\
\hline Weight gain \\
\hline Facial plethora \\
\hline Abdominal mass \\
\hline Abdominal pain \\
\hline Tanner stage for pubic hair \\
\hline $\mathrm{PH} 1$ \\
\hline $\mathrm{PH} 2$ \\
\hline $\mathrm{PH} 3$ \\
\hline $\mathrm{PH} 4$ \\
\hline $\mathrm{PH} 5$ \\
\hline Stature SDS \\
\hline BMI SDS \\
\hline DHEA-S* $(\mu \mathrm{g} / \mathrm{dL})$ \\
\hline Testosterone** (ng/dL) \\
\hline$\Delta$ bone age (months) ${ }^{\star \star \star}$ \\
\hline Tumor hormone profile \\
\hline Androgen-secreting ACT (Virilizing) \\
\hline Androgen and cortisol secreting ACT (Mixed) \\
\hline Tumor stage (IPACTR) \\
\hline 1 \\
\hline II \\
\hline III \\
\hline IV \\
\hline P53 p.R337H mutation \\
\hline Present \\
\hline Absent \\
\hline Data not available \\
\hline During follow-up \\
\hline Chemotherapy \\
\hline Recurrence/metastasis \\
\hline Death \\
\hline Loss of follow-up \\
\hline Discharge after 10 years \\
\hline Duration of follow-up (months) \\
\hline
\end{tabular}

Total $(n=63)$

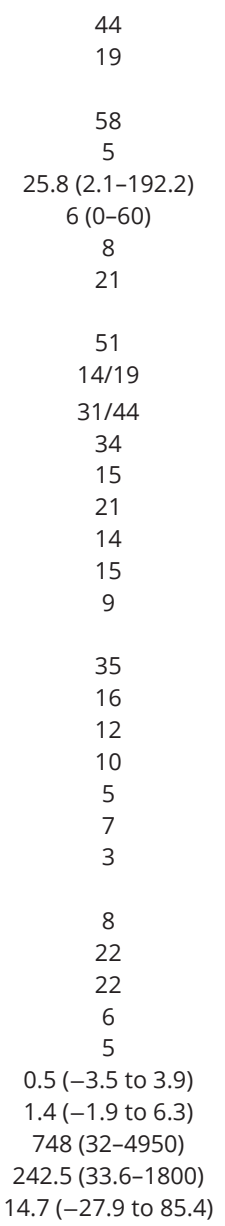

55

38

8

11

6

48

11

17

16

14

16

5

$73.7(0.2-295.4)$

$*_{n}=55 ; * *_{n}=54 ; * * *_{n}=52$

$\mathrm{ACT}$, adrenocortical tumor; BMI, body mass index; DHEA-S, dehydroepiandrosterone sulfate; $\Delta$, delta (difference between bone age and chronological age); IPACTR, International Pediatric Adrenocortical Tumor Registry; PH, pubic hair; SDS, stature standard deviation. received radiotherapy (doses were not available). Fourteen patients died (all deaths were related to ACT complications), 16 lost follow-up and five were discharged after 10 years. Of note, the patients that were discharged after 10 years had the diagnosis of ACT from 1984 to1993. At the time, the risk of developing other types of cancer in adulthood was less known, and there was no specific longterm follow-up protocol for these patients and families.

\section{Pubertal outcomes}

Figure 2 shows the pubertal outcomes among the 63 study patients. To date, 37 patients developed gonadotropindependent puberty: 26 developed puberty within normal age range, one $(\mathrm{F})$ had isolated precocious thelarche, seven (4F: 3M) had CPP and three (F) had EFP. Median time and range (in months) between diagnosis of ACT and pubertal onset were: for normal puberty, 83.8 ( -8.8 to 103.5$)$ in females and $102.4(64.4-113.6)$ in males; for CPP, 34.9 (3.8-73.8) in females and 2.7 (-2.1 to 3.1) in males and for EFP, 40.0 (0.5-94.7). One boy and one girl had developed normal puberty before diagnosis of ACT, but the accurate age was not available. None of the patients had delayed puberty.

Of the 26 patients that did not develop gonadotropindependent puberty: 12 are still on follow-up (current age: 43.5 months (19-99)), while eight died (age: 65.5 months (12-146)) and six lost follow-up (age: 46 months (23-93)) before developing gonadotropin-dependent puberty.

Regarding gonadotropin-releasing hormone analog (GnRHa) treatment, among the three CPP female patients who were treated, one had menarche previously to treatment, at $8 y 5 \mathrm{mo}$, and died before the end of GnRHa treatment, due to ACT advanced disease stage. Another had menarche at $12 \mathrm{y} 4 \mathrm{mo}$, and the last one is currently 9 years old, is still on medication and had no menarche yet. One CPP female patient received no treatment and had menarche at $10 y 3$ mo. One boy with CPP was treated for 8 years, until age 12 . The other two boys with CPP received no treatment, because of multiple ACT-related complications. All three girls with EFP were treated with GnRHa. Menarche occurred in one at $12 y 5 \mathrm{mo}$, one was lost to follow-up and one had no menarche yet.

Additionally, one girl had isolated precocious thelarche at $7 \mathrm{y} 3 \mathrm{mo}$, but had no rapidly progressive puberty and achieved menarche at 13y1mo. Of note, one girl, currently 7y11mo, did not develop puberty yet, but had an isolated precocious vaginal bleeding at age $7 y 3 \mathrm{mo}$.

Table 2 presents the general features of the ten patients with pubertal disorders and the 26 with normal puberty.

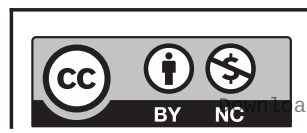

This work is licensed under a Creative Commons Attribution-NonCommercial 4.0 International License. ded from Bioscientifica.com at 04/26/2023 12:15:32AM 


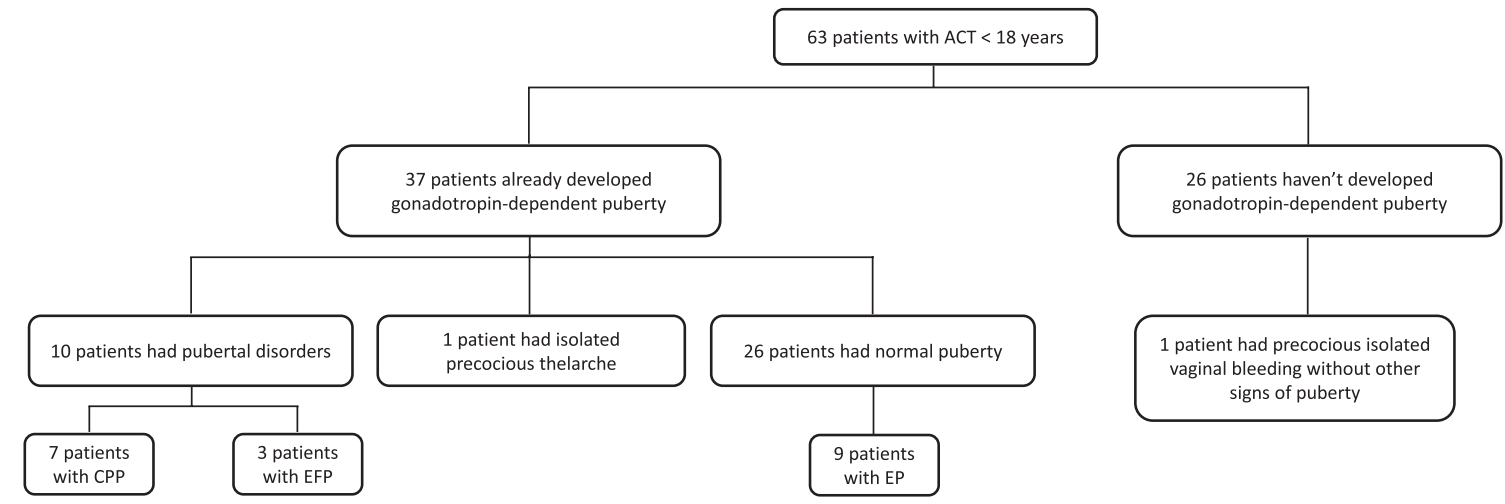

Figure 2

Pubertal outcomes in 63 patients with diagnosis of adrenocortical tumor in childhood.

The patient with isolated precocious thelarche was not included in the comparisons. Patients with CPP and EFP tended be older $(P=0.07)$ and have more advanced BA $(P=0.05)$ at diagnosis of ACT, but there was no difference regarding duration of ACT signs $(P=0.86)$, stature SDS $(P=0.59)$ or DHEA-S and testosterone levels $(P=0.89$ and $P=0.43$, respectively).

At diagnosis of ACT, tall stature was associated with increased risk of developing CPP (RR 4.17 (95\%CI 1.17-14.80)), and older age, with increased risk of developing pubertal disorders (RR 3.0 (95\%CI 1.04-8.65)). During follow-up, the presence of recurrence and/or metastasis was associated with the development of CPP alone (RR 4.17 (95\%CI 1.17-14.80)) and also with pubertal disorders in general (RR 3.0 (95\%CI 1.12-8.02)). There was no association regarding duration of ACT signs, Tanner stage for pubic hair, BA advancement, tumor type, androgen levels or tumor stage at diagnosis of ACT (Tables 3 and 4).

\section{Final height}

$\mathrm{FH}$ was reached in 19 out of 63 patients (8M: 11F). Among these, two patients had adult short stature, with no available target height; none of them had pubertal disorders. All other patients achieved normal stature; the 10 (5M: 5F) for whom target height was available reached their genetic potential. Among these 19 patients, stature SDS dropped from 1.42 at diagnosis of ACT to -0.02 at FH $(P=0.013)$ (Fig. 3).

Of these 19 patients, 14 had normal puberty, three had CPP, one had EFP and one had precocious thelarche. There was no difference in FH SDS between patients with normal puberty and pubertal disorders $(P=0.75)$ (Fig. 3).

\section{Discussion}

There are scanty data on the late consequences of early exposure to high androgen levels on pubertal development and FH of patients with childhood ACTs. This retrospective cohort study, performed in a single reference center, clearly shows that gonadotropin-dependent pubertal disorders are common in patients who previously had androgen-secreting ACTs during childhood. Additionally, it confirms that FH is usually not impaired in this group of patients.

The general features of the patients from this cohort were similar to previously published series $(19,24$, $34,42,43)$. The majority were female $(44 / 63)$, had the diagnosis of ACT before the age of 4 years (44/63), with clinical presentation of a virilizing syndrome (54/63) and harbored the P53 p.R337H mutation (48/52). Despite the predominance of clinical signs of androgen excess, routine assessment of cortisol autonomous secretion (17) revealed that most ACTs (55/63) had a mixed pattern of hormone secretion. All patients underwent open surgery, and some had adjuvant chemotherapy, based on tumor stage, as it is preconized (29). Of note, radiotherapy is not routinely recommended for ACT patients, but it was used for three patients from 1986 to 1988, when mitotane and other chemotherapy agents were not easily available.

The development of CPP after prolonged androgen exposure, especially after its withdrawal, has been welldocumented in CAH $(3,4,5,6)$, Leydig cell tumors $(8,9$, $10,11,12,13,14,15)$, familial male-limited precocious puberty (FMPP) (7) and even in interpersonal transfer of testosterone gel (16). The mechanisms that trigger secondary HPG axis activation are not well understood, but the temporal correlation between skeletal maturation and HPG axis maturation may be a clue (44). A study on male patients with CAH or FMPP showed an association

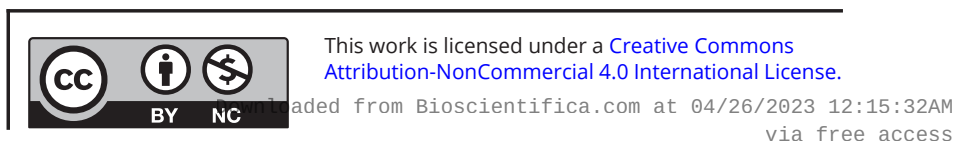


Table 2 General features of the 36" patients with adrenocortical tumor that developed gonadotropin-dependent puberty during follow-up.

\begin{tabular}{|c|c|c|}
\hline Features & $\begin{array}{c}\text { Pubertal } \\
\text { disorders }(n=10)\end{array}$ & $\begin{array}{c}\text { Normal puberty } \\
\quad(n=26)\end{array}$ \\
\hline \multicolumn{3}{|l|}{ At diagnosis of ACT } \\
\hline \multicolumn{3}{|l|}{ Sex } \\
\hline Female & 7 & 15 \\
\hline Male & 3 & 11 \\
\hline \multicolumn{3}{|l|}{ Skin color } \\
\hline White & 10 & 26 \\
\hline Age (months) & $\begin{array}{c}67.7 \\
(5.3-95.5)\end{array}$ & $\begin{array}{c}24.7 \\
(4.7-192.2)\end{array}$ \\
\hline $\begin{array}{l}\text { Duration of ACT } \\
\text { signs (months) }\end{array}$ & $6(1-12)$ & $6(1.5-18)$ \\
\hline \multicolumn{3}{|l|}{$\begin{array}{l}\text { Tanner stage for } \\
\text { pubic hair }\end{array}$} \\
\hline $\mathrm{PH} 1$ & 1 & 3 \\
\hline $\mathrm{PH} 2$ & 4 & 9 \\
\hline $\mathrm{PH} 3$ & 4 & 10 \\
\hline $\mathrm{PH} 4$ & 0 & 2 \\
\hline $\mathrm{PH} 5$ & 1 & 2 \\
\hline Stature SDS & $\begin{array}{c}1.63 \\
(-1.96 \text { to } 2.44)\end{array}$ & $\begin{array}{c}1.29 \\
(-3.55 \text { to } 3.29)\end{array}$ \\
\hline BMI SDS & $\begin{array}{c}1.07 \\
(-0.31 \text { to } 5.22)\end{array}$ & $\begin{array}{c}1.44 \\
(-0.63 \text { to } 3.22)\end{array}$ \\
\hline DHEA-S ( $\mu \mathrm{g} / \mathrm{dL})$ & 735 (33-3968) & $763(32-4678)^{\star}$ \\
\hline Testosterone (ng/dL) & $381(58-900)$ & $\begin{array}{c}235 \\
(33.6-1728)^{*}\end{array}$ \\
\hline$\Delta$ bone age (months) & $\begin{array}{c}37.7 \\
(-1.5 \text { to } 79.7)^{\star *}\end{array}$ & $\begin{array}{c}19.7 \\
(-5.6 \text { to } 49.1)^{\star \star *}\end{array}$ \\
\hline \multicolumn{3}{|l|}{$\begin{array}{l}\text { Tumor hormone } \\
\text { profile }\end{array}$} \\
\hline Virilizing-ACT & 0 & 6 \\
\hline Mixed-ACT & 10 & 20 \\
\hline \multicolumn{3}{|l|}{ Tumor stage (IPACTR) } \\
\hline I & 5 & 18 \\
\hline II & 1 & 4 \\
\hline III & 4 & 2 \\
\hline IV & 0 & 2 \\
\hline \multicolumn{3}{|l|}{ P53 p.R337H mutation } \\
\hline Present & 8 & 20 \\
\hline Absent & 1 & 2 \\
\hline $\begin{array}{l}\text { Data not available } \\
\text { During follow-up }\end{array}$ & 1 & 4 \\
\hline Chemotherapy & 6 & 5 \\
\hline $\begin{array}{l}\text { Recurrence/ } \\
\text { metastasis }\end{array}$ & 5 & 4 \\
\hline Death & 4 & 2 \\
\hline Loss of follow-up & 0 & 9 \\
\hline $\begin{array}{l}\text { Discharge after } \\
10 \text { years }\end{array}$ & 1 & 3 \\
\hline $\begin{array}{l}\text { Duration of follow-up } \\
\text { (months) }\end{array}$ & $\begin{array}{c}78.8 \\
(4-247.6)\end{array}$ & $\begin{array}{c}150.3 \\
(8.2-295.4)\end{array}$ \\
\hline
\end{tabular}

\#The patient with precocious thelarche was not included in the analysis; ${ }^{*} n=23 ;{ }^{* *} n=8 ;{ }^{* * *} n=22$.

ACT, adrenocortical tumor; BMI, body mass index; DHEA-S, dehydroepiandrosterone sulfate; $\Delta$, delta (difference between bone age and chronological age); IPACTR, International Pediatric Adrenocortical Tumor Registry; PH, pubic hair; SDS, stature standard deviation. between the most severe skeletal advancement and the earliest age of gonadotropin-dependent puberty (44). In another study, CAH patients with more advanced BA, more rapid linear growth and taller stature during the first 2 years of life also developed CPP (5). The occurrence of gonadotropin-dependent pubertal disorders mainly after treatment of the underlying disorder may be explained by the withdrawal of a peripheral inhibitor of HPG axis, such as testosterone, in a patient with advanced BA (31). It is known that the decrease in testosterone levels during therapy may lead to secondary CPP in boys with FMPP, for example (7).

In ACTs, the development of CPP has been considered rare (18). There are only scarce studies reporting gonadotropin-dependent pubertal disorders after treatment of ACT. These studies are either small series $(18,31,33,34)$ or larger series in which the number of patients that reached pubertal age is not stated; therefore, the proportion of pubertal disorders cannot not be accurately calculated $(19,24)$. In the present study, this issue was addressed in a straight line. Indeed, 37 out of 63 patients developed gonadotropin-dependent puberty, and, among them, 10/37 had pubertal disorders. Thus, for the first time, a great number of ACT patients were followed until puberty, allowing us to clearly demonstrate that gonadotropin-dependent pubertal disorders are common in patients that had androgen-secreting ACTs during childhood.

In the present study, tall stature at diagnosis of ACT was associated with the development of CPP, and more patients with pubertal disorders had advanced BA at diagnosis of ACT, compared with those with normal puberty. In accordance to these data, the patients that developed CPP or EFP from previous reports $(18,31,33,34)$ had tall stature and advanced BA at diagnosis of ACT. Although the duration of ACT signs before the diagnosis of ACT was not associated with the development of pubertal disorders, this study demonstrated that recurrence and/or metastasis increased the risk of CPP, as well as of pubertal disorders in general. These conditions may lengthen the period of androgen exposure, contributing to the skeletal maturation and further HPG axis activation. At last, there was an association between older age at diagnosis of ACT and the development of pubertal disorders, which may be explained by the proximity to the actual pubertal age. Indeed, a study of hypothalamic stimulation with clomiphene citrate in six children with CAH and one boy with ACT showed that luteinizing hormone response increases with chronological age and, more particularly, with BA (45). https://ec.bioscientifica.com

https://doi.org/10.1530/EC-19-0141
(C) 2019 The authors Published by Bioscientifica Ltd
This work is licensed under a Creative Commons Attribution-NonCommercial 4.0 International License. ded from Bioscientifica.com at 04/26/2023 12:15:32Am via free access 
Table 3 Relative risk for the development of central precocious puberty in pediatric patients with history of adrenocortical tumors.

\begin{tabular}{|c|c|}
\hline Features at diagnosis of ACT & \\
\hline$N$ & \\
\hline Sex & $\mathrm{F}$ \\
\hline & M \\
\hline Age at diagnosis & $\geq 48$ months \\
\hline & $<48$ months \\
\hline Duration of act signs & $\geq 6$ months \\
\hline & $<6$ months \\
\hline Tanner stage - pubic hair & $>\mathrm{PH} 2$ \\
\hline & $\leq \mathrm{PH} 2$ \\
\hline Stature SDS & $>2$ \\
\hline & $\leq 2$ \\
\hline Bone age & Advanced \\
\hline & Not advanced \\
\hline DHEA-S ( $\mu \mathrm{g} / \mathrm{dL})$ & $\geq 300$ \\
\hline & $<300$ \\
\hline Testosterone (ng/dL) & $\geq 300$ \\
\hline & $<300$ \\
\hline Tumor hormone profile & V-ACT \\
\hline & M-ACT \\
\hline Tumor stage & III and IV \\
\hline & I and || \\
\hline Recurrence/metastasis (during follow-up) & Present \\
\hline & Absent \\
\hline
\end{tabular}

\begin{tabular}{l}
\hline CPP \\
\hline 7 \\
4 \\
3 \\
4 \\
3 \\
4 \\
3 \\
4 \\
3 \\
4 \\
3 \\
5 \\
1 \\
5 \\
2 \\
4 \\
3 \\
0 \\
7 \\
3 \\
4 \\
4 \\
3 \\
\hline
\end{tabular}

$\begin{array}{r}\hline \mathbf{N P} \\ \hline 26 \\ 15 \\ 11 \\ 6 \\ 20 \\ 14 \\ 12 \\ 15 \\ 11 \\ 4 \\ 22 \\ 13 \\ 9 \\ 17 \\ 6 \\ 8 \\ 15 \\ 6 \\ 20 \\ 4 \\ 22 \\ 4 \\ 22 \\ \hline\end{array}$

\begin{tabular}{c}
\hline $\mathbf{R R}$ \\
\hline 0.98 \\
3.07 \\
1.11 \\
0.98 \\
4.17 \\
2.78 \\
0.91 \\
2.00 \\
* \\
2.78 \\
4.17 \\
\hline
\end{tabular}

$\frac{\text { Cl 95\% }}{(0.26-3.71)}$

*Not done.

ACT, adrenocortical tumor; CPP, central precocious puberty; DHEA-S, dehydroepiandrosterone sulfate; $\Delta$, delta (difference between bone age and chronological age; M-ACT, androgen and cortisol-secreting ACT (mixed-ACT); NP, normal puberty; RR, relative risk; SDS, stature standard deviation; V-ACT, androgen-secreting ACT (virilizing-ACT).

GnRHa have been shown to be effective for the treatment of secondary CPP, and their indications include prevention of precocious menarche in girls and adult short stature, as well as psychosocial maladjustment, in both sexes $(1,2)$. In the present study, GnRHa effectively treated the patients with gonadotropin-dependent pubertal disorders. Menarche occurred at an appropriate age for the treated patients, and the one with an episode of vaginal bleeding before GnRHa treatment presented no recurrence. Additionally, treated patients reached normal FH, within the genetic potential. However, due to the small number of patients with pubertal disorders that reached $\mathrm{FH}$, comparison between treated and not treated patients was not possible. Treatment with GnRHa or cyproterone acetate had only been reported in three cases of CPP in patients with ACT, but there is no information on menarche or FH of these patients $(18,31,33)$.

It is well known that hyperfunction of the adrenal cortex in childhood, with elevated secretion of androgens and glucocorticoids, may cause significant disturbance of linear growth. While androgen excess advances growth and BA, glucocorticoid excess impairs skeletal maturation (46). In the presence of both, however, the androgen effects appear to dominate the clinical features (47).
This predominance may explain why the majority of patients in this cohort had normal (79.3\%) or tall stature (17.5\%) and advanced BA (63.5\%) at diagnosis of ACT, although most had M-ACT. This finding is in accordance with previous reports $(18,19,24,30,31,32,34,42$, $43,47)$. In addition, the combination of androgen and glucocorticoid effects may have accounted for the lack of difference in initial stature SDS, BMI SDS and $\Delta$ BA between V-ACT and M-ACT. Despite the acceleration of linear growth and skeletal maturation at diagnosis of $\mathrm{ACT}$, there was a reduction of stature SDS from initial to final height, and the majority of patients (17 out of 19) reached normal FH. These results reinforce that growth tends to return to the patient's predetermined channel after successful removal of an androgen-secreting ACT (47), with good prognosis on FH $(18,19,30,32)$.

The retrospective character of this study imposed some limitations. Missing data may have weakened the statistical analysis. The duration of follow-up was different among the study subjects and many did not develop gonadotropin-dependent puberty and/or reach FH because they were still young, died or lost follow-up at the time of the study. Additionally, BA radiographies were not reviewed in a blinded fashion by a single reader,

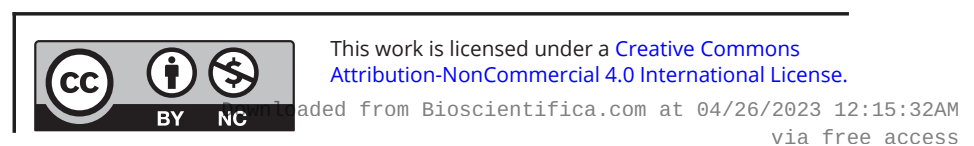


Table 4 Relative risk for the development of central precocious puberty or early fast puberty in pediatric patients with history of adrenocortical tumors.

\begin{tabular}{|c|c|}
\hline Features at diagnosis of ACT & \\
\hline \multicolumn{2}{|l|}{$N$} \\
\hline \multirow[t]{2}{*}{ Sex } & $\mathrm{F}$ \\
\hline & M \\
\hline \multirow[t]{2}{*}{ Age at diagnosis } & $\geq 48$ months \\
\hline & $<48$ months \\
\hline \multirow[t]{2}{*}{ Duration of act signs } & $\geq 6$ months \\
\hline & $<6$ months \\
\hline \multirow[t]{2}{*}{ Tanner stage - pubic hair } & $>\mathrm{PH} 2$ \\
\hline & $\leq \mathrm{PH} 2$ \\
\hline \multirow[t]{2}{*}{ Stature SDS } & $>2$ \\
\hline & $\leq 2$ \\
\hline \multirow[t]{2}{*}{ Bone age } & Advanced \\
\hline & Not advanced \\
\hline \multirow[t]{2}{*}{ DHEA-S $(\mu \mathrm{g} / \mathrm{dL})$} & $\geq 300$ \\
\hline & $<300$ \\
\hline \multirow[t]{2}{*}{ Testosterone (ng/dL) } & $\geq 300$ \\
\hline & $<300$ \\
\hline \multirow{2}{*}{ Tumor hormone profile } & V-ACT \\
\hline & M-ACT \\
\hline \multirow[t]{2}{*}{ Tumor stage } & III/IV \\
\hline & $|/| \mid$ \\
\hline \multirow[t]{2}{*}{ Recurrence/metastasis (during follow-up) } & Present \\
\hline & Absent \\
\hline
\end{tabular}

\begin{tabular}{c}
\hline CPP/EFP \\
\hline 10 \\
7 \\
3 \\
6 \\
4 \\
5 \\
5 \\
6 \\
4 \\
4 \\
6 \\
6 \\
2 \\
8 \\
2 \\
6 \\
4 \\
0 \\
10 \\
4 \\
6 \\
5 \\
5 \\
\hline
\end{tabular}

$\begin{array}{r}\hline \mathbf{N P} \\ \hline 26 \\ 15 \\ 11 \\ 6 \\ 20 \\ 14 \\ 12 \\ 15 \\ 11 \\ 4 \\ 22 \\ 13 \\ 9 \\ 17 \\ 6 \\ 8 \\ 15 \\ 6 \\ 20 \\ 4 \\ 22 \\ 4 \\ 22 \\ \hline\end{array}$

$\begin{array}{r}\hline \mathbf{R R} \\ \hline 1.48 \\ 3.00 \\ 0.90 \\ 1.07 \\ 2.33 \\ 1.74 \\ 1.28 \\ 2.03 \\ \text { * } \\ 2.33 \\ 3.00 \\ \hline\end{array}$

\begin{tabular}{c} 
Cl 95\% \\
\hline$(0.46-4.81)$
\end{tabular}

*Not done.

ACT, adrenocortical tumor; CPP, central precocious puberty; DHEA-S, dehydroepiandrosterone sulfate; $\Delta$, delta (difference between bone age and chronological age; M-ACT, androgen and cortisol-secreting ACT (mixed-ACT); NP, normal puberty; RR, relative risk; SDS, stature standard deviation; V-ACT, androgen-secreting ACT (virilizing-ACT).

since many of the images were unavailable. However, to our knowledge, this is the largest cohort of ACT patients from a single center evaluated for pubertal and $\mathrm{FH}$ outcomes.
In conclusion, this study clearly shows that gonadotropin-dependent pubertal disorders are more common than previously expected in patients with childhood virilizing ACTs. Additionally, it confirms that

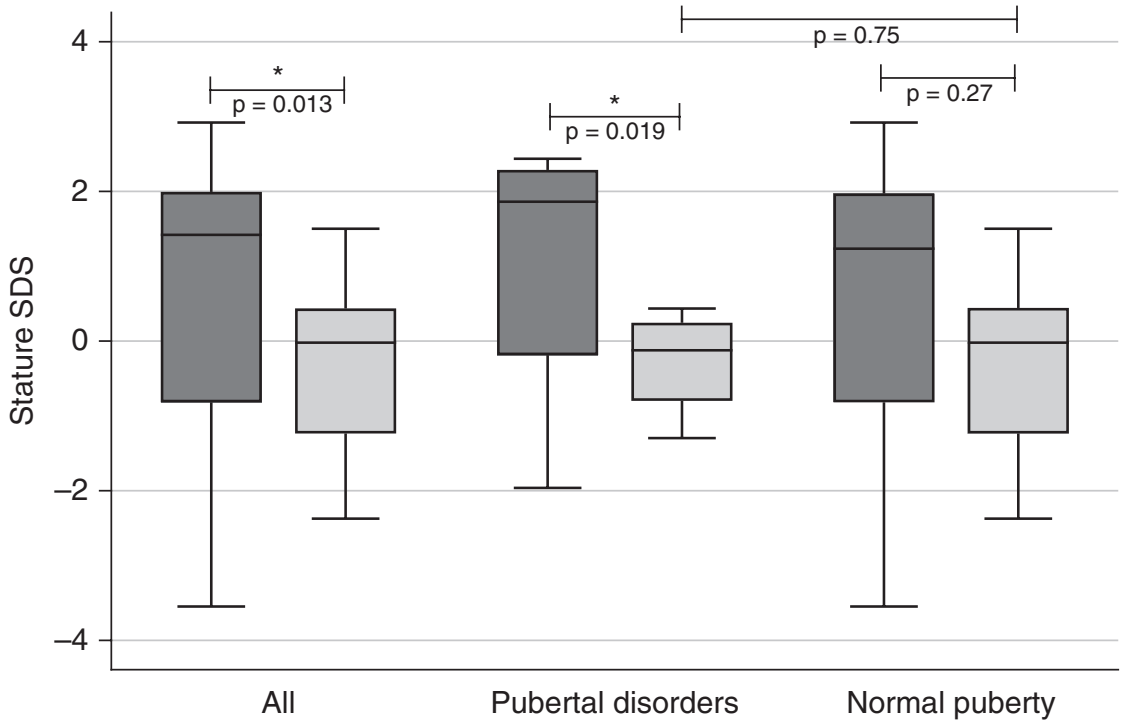

Initial height $\square$ Final height
Figure 3

Initial and final height according to pubertal development in patients with diagnosis of adrenocortical tumor in childhood. https://ec.bioscientifica.com

https://doi.org/10.1530/EC-19-0141 (c) 2019 The authors Published by Bioscientifica Ltd

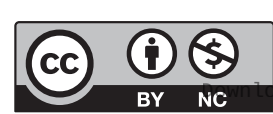

This work is licensed under a Creative Commons Attribution-NonCommercial 4.0 International License. ded from Bioscientifica,com at 04/26/2023 12:15:32AM via free access 
FH is usually not impaired, reiterating the good prognosis for FH in these patients. At last, it reinforces the importance of close and prolonged endocrinology follow-up after surgery, not only to detect ACT-related complications, but also to promptly identify and treat consequences of early exposure to androgen excess.

\section{Declaration of interest}

The authors declare that there is no conflict of interest that could be perceived as prejudicing the impartiality of the research reported.

\section{Funding}

This work was supported by FAPESP (Sao Paulo State Research Agency; Grants \#2015/19663-5 and \#2014/03989-6). M.F.S. and C.B.M. are recipients of research fellowships from CAPES and FAPESP - Brazil, respectively.

\section{Acknowledgments}

The authors are grateful to all medical, health care, laboratory and administrative personnel who were involved in the care of these patients over the last four decades in our institution. In addition, they thank all patients and their families for their trust in our service. They dedicate this work to Professor Romulo Sandrini (Federal University of Parana), whose work with pediatric ACT patients has been an inspiration. In addition, they dedicate this work to the memory of Professor Jose T. Veríssimo, who first diagnosed and treated pediatric ACT patients in our institution in the early 1960 s.

\section{References}

1 Brito VN, Spinola-Castro AM, Kochi C, Kopacek C, Silva PC \& Guerra-Júnior G. Central precocious puberty: revisiting the diagnosis and therapeutic management. Archives of Endocrinology and Metabolism $2016 \mathbf{6 0}$ 163-172. (https://doi.org/10.1590/23593997000000144).

2 Fuqua JS. Treatment and outcomes of precocious puberty: an update. Journal of Clinical Endocrinology and Metabolism 201398 2198-2207. (https://doi.org/10.1210/jc.2013-1024).

3 Dacou-Voutetakis C \& Karidis N. Congenital adrenal hyperplasia complicated by central precocious puberty: treatment with LHRH-agonist analogue. Annals of the New York Academy of Sciences 1993687 250-254. (https://doi.org/10.1111/j.1749-6632.1993. tb43873.x)

4 Speiser PW. Transient central precocious puberty in non-classic 21-hydroxylase deficiency. Journal of Pediatric Endocrinology and Metabolism 19958 287-289. (https://doi.org/10.1515/ JPEM.1995.8.4.287)

5 Soliman AT, Ailamki M, Aisalmi I \& Asfour M. Congenital adrenal hyperplasia complicated by central precocious puberty: linear growth During infancy and treatment With gonadotropin-releasing hormone analog. Metabolism 199746 513-517. (https://doi. org/10.1016/S0026-0495(97)90186-4)

6 Guven A, Cebeci AN \& Hancili S. Gonadotropin releasing hormone analog treatment in children with congenital adrenal hyperplasia complicated by central precocious puberty. Hormones 201514 265-271. (https://doi.org/10.14310/horm.2002.1555).
7 Almeida MQ, Brito VN, Lins TSS, Guerra-Junior G, De Castro M, Antonini SR, Arnhold IJP, Mendonca BB \& Latronico AC. Long-term treatment of familial male-limited precocious puberty (testotoxicosis) with cyproterone acetate or ketoconazole. Clinical Endocrinology 2008 69 93-98. (https://doi.org/10.1111/j.1365-2265.2007.03160.x).

8 Mengel W \& Knorr D. Leydig cell tumours in childhood. Progress in Pediatric Surgery 198316 133-138.

9 Criscoulo T, Sinisi AA, Perrone L, Graziani M, Bellastella A \& Faggiano M. Isosexual precocious pseudopuberty secondary to a testosterone-secreting Leydig cell testicular tumour: true isosexual development early after surgery. Andrologia 198618 175-183. (https://doi.org/10.1111/j.1439-0272.1986.tb01757.x)

10 Ghazi AA, Rahimi F, Ahadi MM \& Sadeghi-Nejad A. Development of true precocious puberty following treatment of a Leydig cell tumor of the testis. Journal of Pediatric Endocrinology and Metabolism 200114 1679-1681. (https://doi.org/10.1515/JPEM.2001.14.9.1679)

11 Kiepe D, Richter-Unruh A, Autschbach F, Kessler M, Schenk JP $\&$ Bettendorf M. Sexual pseudo-precocity caused by a somatic activating mutation of the LH receptor preceding true sexual precocity. Hormone Research 200870 249-253. (https://doi. org/10.1159/000151598).

12 Lignitz S, Partsch CJ, Wudy SA, Hartmann MF \& Pohlenz J. Clinical and metabolic findings in a 6-year-old boy with a Leydig cell tumour. Acta Paediatrica 2011100 280-282. (https://doi.org/10.1111/j.16512227.2011.02338.x)

13 Olivier P, Simoneau-roy J, Francoeur D, Sartelet H, Parma J, Vassart G \& Van Vliet G. Leydig cell tumors in children: contrasting clinical, hormonal, anatomical, and molecular characteristics in boys and girls. Journal of Pediatrics 2012161 1147-1152. (https://doi. org/10.1016/j.jpeds.2012.05.039).

14 Santos-Silva R, Bonito-Vítor A, Campos M \& Fontoura M. Gonadotropin-dependent precocious puberty in an 8-year-old boy with Leydig cell testicular tumor. Hormone Research in Paediatrics 2014 82 133-137. (https://doi.org/10.1159/000358084).

15 Verrotti A, Penta L, Zenzeri L, Lucchetti L, Giovenali P \& De Feo P. True Precocious Puberty Following Treatment of a Leydig Cell Tumor: two case reports and literature review. Frontiers in Pediatrics 20153 93. (https://doi.org/10.3389/fped.2015.00093).

16 Brachet C \& Heinrichs C. Central precocious puberty after interpersonal transfer of testosterone gel: just a coincidence? Journal of Pediatric Endocrinology and Metabolism 201225 757-760. (https:// doi.org/10.1515/jpem-2012-0067).

17 Antonini SR, Leal LF \& Cavalcanti MM. Pediatric adrenocortical tumors: diagnosis, management and advancements in the understanding of the genetic basis and therapeutic implications. Expert Review of Endocrinology and Metabolism 20149 445-464. (https://doi.org/10.1586/17446651.2014.941813)

18 Salt AT, Savage MO \& Grant DB. Growth patterns after surgery for virilising adrenocortical adenoma. Archives of Disease in Childhood 199267 234-236. (https://doi.org/10.1136/adc.67.2.234)

19 Sandrini R, Ribeiro RC \& De LL. Childhood adrenocortical tumors. Journal of Clinical Endocrinology and Metabolism 199782 2027-2031. (https://doi.org/10.1210/jcem.82.7.4057)

20 Latronico AC, Pinto EM, Domenice S, Fragoso MC, Martin RM, Zerbini MC, Lucon AM \& Mendonca BB. An inherited mutation Outside the highly conserved DNA-binding domain of the p53 tumor suppressor protein in children and adults with sporadic adrenocortical tumors. Journal of Clinical Endocrinology and Metabolism 200186 4970-4973. (https://doi.org/10.1210/ jcem.86.10.7957).

21 Ribeiro RC, Sandrini F, Figueiredo B, Zambetti GP, Michalkiewicz E, Lafferty AR, DeLacerda L, Rabin M, Cadwell C, Sampaio G, et al. An inherited p53 mutation that contributes in a tissue-specific manner to pediatric adrenal cortical carcinoma. PNAS 200198 9330-9335. (https://doi.org/10.1073/pnas.161479898). https://ec.bioscientifica.com https://doi.org/10.1530/EC-19-0141 (c) 2019 The authors Published by Bioscientifica Ltd

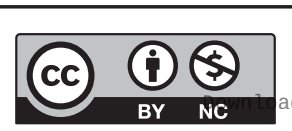

This work is licensed under a Creative Commons Attribution-NonCommercial 4.0 International License. ded from Bioscientifica.com at 04/26/2023 12:15:32AM 
22 Sandrini F, Villani DP, Tucci S, Moreira AC, Castro M \& Elias LLK. Inheritance of $\mathrm{R} 337 \mathrm{H}$ p53 gene mutation in children with sporadic adrenocortical tumor. Hormone and Metabolic Research 2005 . (https:// doi.org/10.1055/s-2005-861373).

23 Leal LF, Mermejo LM, Ramalho LZ, Martinelli CE, Yunes JA, Seidinger AL, Jose MJ, Cardinalli IA, Brandalise SR, Moreira AC, et al. Wnt/beta-catenin Pathway Deregulation in Childhood adrenocortical Tumors. Journal of Clinical Endocrinology and Metabolism 201196 3106-3114. (https://doi.org/10.1210/jc.20110363).

24 Mastellaro MJ, Ribeiro RC, Oliveira-filho AG, Seidinger AL, Cardinalli IA, Miranda ECM, Aguiar SS, Brandalise SR, Yunes JA \& Barros-Filho AA. Adrenocortical tumors associated with the TP53 p.R337H germline mutation can be identified during childhood. Jornal de Pediatria 2017550 1-8. (https://doi.org/10.1016/j. jped.2017.06.009).

25 Achatz MI, Olivier M, Le Calvez F, Martel-Planche G, Lopes A, Rossi BM, Ashton-Prolla P, Giugliani R, Palmero EI, Vargas FR, et al. The TP53 mutation, R337H, is associated with Li-Fraumeni and Li-Fraumeni-like syndromes in Brazilian families. Cancer Letters 2007 245 96-102. (https://doi.org/10.1016/j.canlet.2005.12.039).

26 Kratz CP, Achatz MI, Brugi L, Frebourg T, Garber JE, Greer MC, Hansford JR, Janeway KA, Kohlmann WK, Mcgee R, et al. Cancer screening recommendations for individuals with li-fraumeni syndrome. Clinical Cancer Research 201723 38-46. (doi:10.1158/1078-0432.CCR-17-0408).

27 Lau SK \& Weiss LM. The Weiss system for evaluating adrenocortical neoplasms: 25 years later. Human Pathology 200940 757-768. (https://doi.org/10.1016/j.humpath.2009.03.010).

28 León MIM, Chaparro SR, Lara BW \& Pinos MDD. Tumores corticosuprarrenales pediátricos: imagen de adenomas y carcinomas. Radiologia 201254 342-349. (https://doi.org/10.1016/j. rx.2011.02.005).

29 Ribeiro RC, Pinto EM, Zambetti GP \& Rodriguez-Galindo C. The International Pediatric Adrenocortical Tumor Registry initiative: Contributions to clinical, biological, and treatment advances in pediatric adrenocortical tumors. Molecular and Cellular Endocrinology 2012351 37-43. (https://doi.org/10.1016/j. mce.2011.10.015).

30 Valerio G, Spagnuolo MI, Muzzi G, Buono P, Lombardi F, Palmieri R $\&$ Franzese A. Adrenocortical tumor in a boy: final height is not impaired Despite a severe advancement of bone age. Journal of Pediatric Endocrinology and Metabolism 200316 1061-1063. (https:// doi.org/10.1515/JPEM.2003.16.7.1061)

31 Kim MS, Yang EJ, Cho DH, Hwang PH \& Lee DY. Virilizing adrenocortical carcinoma advancing to central precocious puberty after surgery. Korean Journal of Family Medicine 201536 150-153. (https://doi.org/10.4082/kjfm.2015.36.3.150).

32 Breidbart E, Cameo T, Garvin JH, Hibshoosh H \& Oberfield SE. Pubertal outcome in a female with virilizing adrenocortical carcinoma. Journal of Pediatric Endocrinology and Metabolism 201629 503-509. (https://doi.org/10.1515/jpem-2015-0123.).

33 Ersoy B, Kizilay D, Cayirli H, Temiz P \& Gunsar C. Central precocious puberty secondary to adrenocortical adenoma in a female child: case report and review of the literature. Journal of Pediatric and
Adolescent Gynecology 201730 591-594. (https://doi.org/10.1016/j. jpag.2017.05.009)

34 Lee PD, Winter RJ \& Green OC. Virilizing adrenocortical tumors in childhood: eight cases and a review of the literature. Pediatrics 198576 437-444. (https://doi.org/10.1016/S00225347(17)45676-X)

35 Barstow C \& Rerucha C. Evaluation of short and tall stature in children. American Family Physician 201592 43-50.

36 Tanner J. The use and abuse of growth standards. In Human Growth, 2nd ed., pp 95-112. Eds F Falkner \& J Tanner. New York, NY, USA: Plenumm Press, 1986.

37 Marshall WA \& Tanner JM. Variations in pattern of pubertal changes in girls. Archives of Disease in Childhood 196944 291-303. (https:// doi.org/10.1136/adc.44.235.291).

38 Marshall WA \& Tanner JM. Variations in the pattern of pubertal changes in boys. Archives of Disease in Childhood 197045 13-23. (https://doi.org/10.1136/adc.45.239.13).

39 Greulich WW \& Pyle SI. Radiographic Atlas of Skeletal Development of the Hand and Wrist, 2nd ed. Palo Alto, CA, USA: Stanford University Press, 1959.

40 Lazar L, Kauli R, Pertzelan A \& Phillip M. Gonadotropin-suppressive therapy in girls with early and fast puberty affects the pace of puberty but not total pubertal growth or final height. Journal of Clinical Endocrinology and Metabolism 200287 2090-2094. (https:// doi.org/10.1210/jcem.87.5.8481)

41 Stagi S, Bindi G, Galluzzi F, La Cauza F \& Salti R. Precocious, early and fast puberty in males with Chiari I malformation. Journal of Pediatric Endocrinology and Metabolism 200417 1137-1140. (https:// doi.org/10.1515/JPEM.2004.17.8.1137)

42 Ribeiro RC, Neto RS, Schell MJ, Lacerda L, Sambaio GA \& Cat I. Adrenocortical carcinoma in children: a study of 40 cases. Journal of Clinical Oncology 19908 67-74. (https://doi.org/10.1200/ JCO.1990.8.1.67)

43 Wolthers OD, Cameron FJ, Scheimberg I, Honour JW, Hindmarsh PC, Savage MO, Stanhope RG \& Brook CG. Androgen secreting adrenocortical tumours. Archives of Disease in Childhood 199980 46-50. (https://doi.org/10.1136/adc.80.1.46)

44 Flor-cisneros A, Leschek EW, Merke DP, Barnes KM, Coco M, Cutler Jr GB \& Baron J. In boys with abnormal developmental tempo, maturation of the skeleton and the hypothalamic-pituitarygonadal axis remains synchronous. Journal of Clinical Endocrinology and Metabolism 200489 236-241. (https://doi.org/10.1210/jc.2002021954).

45 Moreira AC, Veríssimo JM, Foss MC, Iazigi N, Maciel LM, Pimenta WD, Rodrigues JA \& Santoro JR. Pubertal maturation of the LH stimulatory response to clomiphene citrate in congenital virilizing adrenal hyperplasia. Clinical Endocrinology 198217 441-447. (https://doi.org/10.1111/j.1365-2265.1982.tb01611.x)

46 Savage MO, Scommegna S, Carroll PV, Ho JT, Monson JP, Besser GM \& Grossman AB. Growth in disorders of adrenal hyperfunction. Hormone Research 200258 39-43. (https://doi. org/10.1159/000064767).

47 Hauffa BP, Roll C, Mühlenberg R \& Havers W. Growth in children with adrenocortical tumors. Klinische Padiatrie 1991203 83-87. (https://doi.org/10.1055/s-2007-1025405)

Received in final form 20 March 2019

Accepted 4 April 2019

Accepted Preprint published online 4 April 2019 https://ec.bioscientifica.com https://doi.org/10.1530/EC-19-0141
(C) 2019 The authors Published by Bioscientifica Ltd

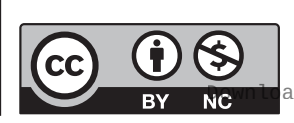

This work is licensed under a Creative Commons Attribution-NonCommercial 4.0 International License. ded from Bioscientifica com at $04 / 26 / 2023$ 12:15:32AM 